\title{
Enhancement of oxidation of dimethyl ether through application of zirconia matrix for immobilization of noble metal catalytic nanoparticles
}

\author{
Iwona A. Rutkowska ${ }^{1} \cdot$ Jakub P. Sek $^{1} \cdot$ Piotr Zelenay $^{1,2} \cdot$ Pawel J. Kulesza $^{1}$ (D) \\ Received: 5 June 2020 / Revised: 25 July 2020 / Accepted: 26 July 2020 / Published online: 7 August 2020 \\ (C) The Author(s) 2020
}

\begin{abstract}
Electrocatalytic activity of Pt and bimetallic PtRu nanoparticles (both Vulcan supported and unsupported) toward electrooxidation of dimethyl ether (DME), a potential small organic molecule fuel, in an acid medium $\left(0.5 \mathrm{~mol} \mathrm{dm}^{-3} \mathrm{H}_{2} \mathrm{SO}_{4}\right)$ has been significantly enhanced by dispersing them over a thin film of zirconia $\left(\mathrm{ZrO}_{2}\right)$. The enhancement effects concern increases of the DME electrocatalytic current densities recorded under both cyclic voltammetric and chronoamperometric conditions. Similar effects have been observed for the oxidation of methanol. Regarding the dissimilar DME electrooxidation mechanisms at Pt and PtRu catalytic centers, the activating capabilities of zirconia seem to originate from the high population of reactive - $\mathrm{OH}$ groups favoring mobility of protons and the capability of inducing the oxidative removal of poisoning (CO-type) intermediates both at platinum and ruthenium catalytic sites. In the presence of the zirconia matrix, the onset potential for the oxidation of DME (particularly at PtRu) is shifted more than $50 \mathrm{mV}$ toward less positive potentials. Mutual metal-support interactions are also postulated.
\end{abstract}

Keywords Dimethyl ether $\cdot$ Methanol $\cdot$ Catalytic electrooxidation $\cdot$ Pt and PtRu nanoparticles $\cdot$ Zirconia support

\section{Introduction}

There has been growing interest in low-temperature fuel cells [1-7] during recent years, and the hydrogen-oxygen fuel cell is technologically the most advanced and the most commonly considered for practical purposes. In addition to hydrogen energy carrier, simple (small) organic molecules are also considered as potential fuels [8]. On scientific grounds, the limitations of fuel cells concern low efficiencies of electrocatalytic systems during oxidations of fuels in addition to limited stability of conventional electrocatalysts, the poisoning effects

Dedicated to Prof. Dr. Fritz Scholz on occasion on His 65th Birthday

Iwona A. Rutkowska

ilinek@chem.uw.edu.pl

Pawel J. Kulesza

pkulesza@chem.uw.edu.pls

1 Faculty of Chemistry, University of Warsaw, Pasteura 1, PL-02-093 Warsaw, Poland

2 Los Alamos National Laboratory, Materials Physics and Applications, Los Alamos, NM 87545, USA originating from strong adsorption of the undesirable reaction intermediates, as well as the fuel crossover through the membrane, which tends to depolarize the cathode and decreases its activity [1-3, 8-12].

Methanol, the simplest alcohol, is often considered as an alternative fuel to hydrogen in certain applications [8]. However, practical performance of the methanol-based systems is limited by several factors, which include the slow electrode kinetics of methanol oxidation, the alcohol crossover from the anode to the cathode side of the cell, and toxic features of the methanol reagent itself. More recently, dimethyl ether $\left(\mathrm{CH}_{3} \mathrm{OCH}_{3}\right)$, DME, a basically non-toxic gas commonly used in aerosol propellants, solvents, and coolants, has been a subject of the fuel cell research and studies aiming at elucidation of the DME oxidation mechanisms [13-20]. When oxidized to $\mathrm{CO}_{2}$, a $\mathrm{CH}_{3} \mathrm{OCH}_{3}$ molecule releases 12 electrons according to the following overall reaction:

$\mathrm{CH}_{3} \mathrm{OCH}_{3}+3 \mathrm{H}_{2} \mathrm{O} \rightarrow 2 \mathrm{CO}_{2}+12 \mathrm{H}^{+}+12 \mathrm{e}^{-}$

Unlike ethanol $\left(\mathrm{CH}_{3} \mathrm{CH}_{2} \mathrm{OH}\right)$, the oxidation of DME does not require the breaking of the $\mathrm{C}-\mathrm{C}$ bond. In addition, the ether (DME) has potentially higher energy density relative to 
methanol (namely, 8.2 vs. $6.1 \mathrm{kWh} \mathrm{kg}^{-1}$ ). The theoretical open cell potential difference of the direct dimethyl ether fuel cell would be close to that of the methanol one $(1.18 \mathrm{~V}$ vs. $1.21 \mathrm{~V})$ [21]. To date, the mechanism of the dimethyl ether oxidation has not been fully identified, and there is a need to develop or optimize catalysts designed specifically for the respective DME anodes. Electrochemical investigations in aqueous solutions imply that electrooxidation of DME on Pt occurs preferentially at low $\mathrm{pH}$ values whereas the process barely proceeds under basic conditions. It has been postulated that protonation of the oxygen atom in the ether molecule (following its adsorption on the Pt catalyst surface) plays a key role, as well as the reaction scheme involves the formation of the adsorbed CO [22-24].

Based on situ infrared (IR) spectroscopic studies [14, 23, $25,26]$, various intermediate adsorbate species, such as $\left(\mathrm{CH}_{3} \mathrm{OC}-\right)_{\text {ads }}, \mathrm{CO}_{\text {linear }}$ (linearly bonded $\mathrm{CO}$ ), and $\mathrm{CO}_{\text {bridge }}$ (bridge bonded $\mathrm{CO}$ ), have been postulated to appear on Ptbased catalytic surfaces during oxidation of DME. In addition, such reaction intermediates as $\left(\mathrm{CH}_{3} \mathrm{COO}^{-}\right)_{\text {ads }}$, $\left(\mathrm{CH}_{3} \mathrm{OCOO}^{-}\right)_{\text {ads }}$ [21], and $\left(\mathrm{HCOO}^{-}\right)$ads $[14]$ have also been identified thus implying the feasibility of complex mechanisms during the DME oxidation.

As in the case of methanol oxidation in acid media [8, 27-30], the addition of ruthenium to form bimetallic PtRu makes the catalyst to operate during the DME oxidation at lower over-potentials with better tolerance to poisoning with the CO-type intermediates [6, 31]. It has been rationalized that a high activation barrier for the $\mathrm{C}-\mathrm{O}$ bond cleavage in the DME molecule is responsible for the relative kinetics of DME oxidation in comparison with methanol. Among noble metals, $\mathrm{Pd}$ exhibits activity toward the $\mathrm{C}-\mathrm{O}$ bond splitting in ethers $[13,16,22,23]$ and, therefore, the addition of Pd to the $\mathrm{PtRu}$ catalysts have been reported to enhance electrocatalytic oxidation of DME [13, 17, 24].

The concept of addition of a second activating metal component to platinum $[8,32-36]$ is well established with respect to the oxidation of $\mathrm{CO}$, methanol, and other alcohols. For example, the addition of tungsten [37], tin [38], and molybdenum [39] has been reported to improve the catalytic activity of platinum during the methanol oxidation reaction. In general, alloys such as PtRu, PtFe, PtNi, PtCo, and PtMo show good tolerance to $\mathrm{CO}$ poisoning [40]. In comparison with simple Pt, the catalytic activity of bimetallic systems, PtRu and PtSn, have had lower onset potentials for the DME electrooxidation $[31,36]$, particularly, when the Vulcan-supported catalytic nanoparticles have been considered [41].

Immobilization of catalytic metal nanoparticles on robust conducting supports characterized by high surface area and suitable porosity tends to improve their dispersion, in addition to facilitating the reactant flow under practical conditions [42-44]. Nanostructured carbon carriers, including Vulcan $\mathrm{XC}-72$ carbon black or even carbon nanotubes are good candidates for immobilization of catalytic nanoparticles [45, 46]. Application of certain transition metal oxides as matrices can also induce activity of catalytic nanoparticles due to their unique adsorptive properties, large electrochemically active surface area, and, in some cases, specific chemical reactivity $[8,47-51]$. In addition to such features as the existence of distinct oxidation states as well as the mixed electronic and ionic conductivity, the metal oxide surfaces become readily covered with hydroxyl groups, thus favoring hydrophilicity, proton mobility, and strong acidity of the electrocatalytic interface [8, 51-54]. Among other important issues is the presence of bulk and surface states that influence the catalytic activity of oxide films [55]. Adsorptive interactions of small organic molecules with highly porous metal oxides are also possible.

In the present work, we consider hybrid electrocatalytic systems (for DME oxidation) utilizing nanostructured zirconia $\left(\mathrm{ZrO}_{2}\right)$ matrices (layers) for dispersing two types of model distinct catalytic metal nanoparticles (Pt and PtRu) both in the pristine (unsupported) form and supported onto carbon (Vulcan) carriers. Utilization of zirconium(IV) oxide (zirconia) is well-established in catalysis, elevatedtemperature oxygen-sensing, high interfacial acidity, and in many processes of industrial importance [8, 56-59]. Under electrochemical conditions, due to large populations of hydroxyl groups on $\mathrm{ZrO}_{2}$ surfaces with polynuclear zirconyl $\left(\mathrm{ZrO}^{2+}\right.$ or $\left.\mathrm{Zr}(\mathrm{OH})^{3+}\right)$-type ionic clusters, desorption of $\mathrm{CO}$ adsorbates from the catalytic $\mathrm{Pt}$ centers has been postulated $[8,60,61] . \mathrm{ZrO}_{2}$ exhibits good stability during electrochemical measurements. Synergistic interactions between ruthenium and zirconia components have been postulated [8, 52, $54,62,63]$ during electrocatalytic oxidations, which are likely to be operative during oxidation of DME as well.

The information about the electrocatalytic properties is based on cyclic voltammetric and chronoamperometric measurements in the $\mathrm{H}_{2} \mathrm{SO}_{4}$ solutions saturated with DME (concentration, $1.05 \mathrm{~mol} \mathrm{dm}^{-3}$ ). Comparative measurements are done in methanol solutions. While the degree of dispersion and the electrochemically active surface area of the Vulcan-supported nanoparticles are superior, relative to the pristine (unsupported) metal catalysts, the studies involving later (Vulcan-free) systems permit more undisputable verification of the influence of zirconia on the activity of $\mathrm{Pt}$ and PtRu during the DME oxidation. It is apparent from the results obtained that the electrocatalytic current densities for the DME oxidation have increased upon dispersing Pt and PtRu catalysts (pristine or Vulcan supported) onto nanostructured zirconia matrices. Nevertheless, the activating capabilities of zirconia are likely to be somewhat different for Pt and PtRu, and dissimilar electronic or chemical interactions of zirconia with bare $\mathrm{Pt}$ and $\mathrm{Ru}$-containing bimetallic PtRu sites are expected. 


\section{Experimental}

All chemicals were analytical grade materials and were used as received. Solutions were prepared from the distilled and subsequently deionized water. They were deoxygenated by bubbling with ultrahigh purified nitrogen. Experiments were carried out at room temperature $\left(22 \pm 2{ }^{\circ} \mathrm{C}\right)$.

Chemical reagents were analytical grade materials. Zirconium(IV) oxide nanoparticles, $5 \mathrm{wt} \%$ dispersion in water, and 5\% Nafion-1100 solution were purchased from Aldrich. Platinum black and platinum-ruthenium black (50:50 wt\%) nanoparticles were obtained from Alfa Aesar. Sulfuric acid was from POCH (Poland).

All electrochemical measurements were performed using $\mathrm{CH}$ Instruments (Austin, TX, USA) 760D workstations in a three-electrode configuration. The reference electrode was the $\mathrm{K}_{2} \mathrm{SO}_{4}$-saturated $\mathrm{Hg}_{2} \mathrm{SO}_{4}$ electrode, and a carbon rod was used as a counter electrode. As a rule, reported here were recalculated and expressed vs. reversible hydrogen electrode (RHE). Glassy carbon disk (geometric area, $0.071 \mathrm{~cm}^{2}$ ) working electrodes were utilized as substrates onto zirconia $\left(\mathrm{ZrO}_{2}\right)$ films or inks of catalytic nanoparticles were immobilized.

Deposition of the $\mathrm{ZrO}_{2}$ film (on the glassy carbon electrode substrate) was performed as before [62, 64-69] via sol-gel aggregation induced by the repetitive voltammetric cycling ( 25 full potential cycles at $10 \mathrm{mV} \mathrm{s}^{-1}$ from 0.04 to $1.04 \mathrm{~V}$ vs. RHE) in the solution for modification obtained by dispersing $0.3 \mathrm{ml}$ of $5 \% \mathrm{wt}$. aqueous suspension of $\mathrm{ZrO}_{2}$ nanoparticles in $30 \mathrm{ml} 0.5 \mathrm{~mol} \mathrm{dm}{ }^{3} \mathrm{H}_{2} \mathrm{SO}_{4}$. Thickness of the resulting $\mathrm{ZrO}_{2}$ film was ca.200-300 nm, as established earlier using profilometry $[62,66]$. The mass loading of such $\mathrm{ZrO}_{2}$ layer was on the level of $1 \mu \mathrm{g} \mathrm{cm}^{-2}$. The diffraction pattern of the $\mathrm{ZrO}_{2}$ film showed peaks characteristic of a monoclinic phase [63].

Suspensions (inks) of metal (Pt and PtRu) nanoparticles (with and without Vulcan) were prepared by dispersing $7.1 \mathrm{mg}$ of the commercial samples through sonication for $120 \mathrm{~min}$ in $2.0 \mathrm{~cm}^{3}$ of distilled water to obtain a homogenous mixture. Later, $2 \mu \mathrm{dm}^{3}$ of the ink was placed onto the film surface to yield the following noble metal loadings$100 \mu \mathrm{g} \mathrm{cm}^{-2}$ in the case of unsupported Pt and $20 \mu \mathrm{g} \mathrm{cm}^{-2}$ for Vulcan-supported Pt and PtRu.

To prepare catalytic layers utilizing $\mathrm{ZrO}_{2}$-supported metal nanoparticles with and without Vulcan, the first step involved the deposition of the zirconium oxide matrix. After the drying step under ambient conditions for $1.5 \mathrm{~h}, 2.0 \mu \mathrm{dm}^{3}$ of the appropriate suspension of metal catalytic nanoparticles (bare or Vulcan supported) was placed onto the film surface.

As a rule, the films were over-coated and stabilized with ultrathin layers of Nafion polyelectrolyte by introducing $1 \mu \mathrm{dm}^{3}$ of the Nafion solution, which was prepared by dispersing the commercial Nafion (5\%mass) solution into ethanol at the 1 to 10 volumetric ratio.
The catalytic materials (films) were first pre-treated in the deaerated $0.5 \mathrm{~mol} \mathrm{dm}^{-3} \mathrm{H}_{2} \mathrm{SO}_{4}$ electrolyte by subjecting them to repetitive potential cycling (in the range from 0.04 to $1.04 \mathrm{~V}$ vs. RHE) at $10 \mathrm{mV} \mathrm{s}^{-1}$ for $30 \mathrm{~min}$. Before the actual electrocatalytic experiments were performed, the electrodes were conditioned by potential cycling (10 full potential cycles at $10 \mathrm{mV} \mathrm{s}^{-1}$ ) in the potential range from 0.04 to $1.04 \mathrm{~V}$ (vs. RHE) in the solution of $0.5 \mathrm{~mol} \mathrm{dm}^{-3} \mathrm{HCOOH}$ in $0.5 \mathrm{~mol} \mathrm{dm}^{-3} \mathrm{H}_{2} \mathrm{SO}_{4}$. Before each representative voltammogram was recorded, the working electrode was kept for $20 \mathrm{~s}$ ("quiet time") at the starting potential.

Transmission electron microscopy (TEM) images of $\mathrm{ZrO}_{2}$ nanoparticles were obtained with JEM 1400 (JEOL Co., Japan, 2008) equipped with high-resolution digital camera (CCD MORADA, SiS-Olympus, Germany).

The morphology of films was investigated by a scanning electron microscope (SEM) with Roentec model M1, EDX analyzer (Germany) integrated with LEO, model $435 \mathrm{VP}$ with accelerating voltage $15 \mathrm{kV}$.

Atomic force microscopy (AFM) experiments were performed with a 5500AFM instrument from Agilent Technologies (Santa Clara, CA, USA). The images were recorded in air using the intermittent contact mode with PPPNCSTR cantilevers (Nanosensors).

Infrared spectra were measured using Shimadzu 8400 FTIR spectrometer equipped with the infrared reflectance absorption spectra (IRRAS) module, Specular Reflectance Accessory Model 500 (from Spectra Tech). The beam incidence angle was equal to $80^{\circ}$ with respect to the surface normal. Typically, 1000 scans were averaged for a single reflectance spectrum.

\section{Results and discussion}

\section{Preparation and physicochemical identity of zirconia films and catalytic nanoparticles}

Figure 1 illustrates (a) transmission electron microscopic (TEM) image of zirconium oxide nanoparticles used for the preparation of the colloidal solutions for the deposition of $\mathrm{ZrO}_{2}$ films under conditions of voltammetric potential cycling. The actual images of the zirconia films (deposited on glassy carbon) have been taken using (b) scanning electron microscopy (SEM) and (c) atomic force microscopy (AFM). While pristine $\mathrm{ZrO}_{2}$ nanoparticles (Fig. 1a) are spherical with diameters ranging from 10 to $15 \mathrm{~nm}$, following deposition on glassy carbon electrode surfaces, the zirconia nanostructures tend to somewhat coalesce to form agglomerates having typical sizes on the level 20-30 nm (Fig. $1 \mathrm{~b}$ and c). As in our previous study [62], the microscopic results are consistent with the high porosity and granular morphology of $\mathrm{ZrO}_{2}$ films. Relative to our previous investigations [62], the actual 

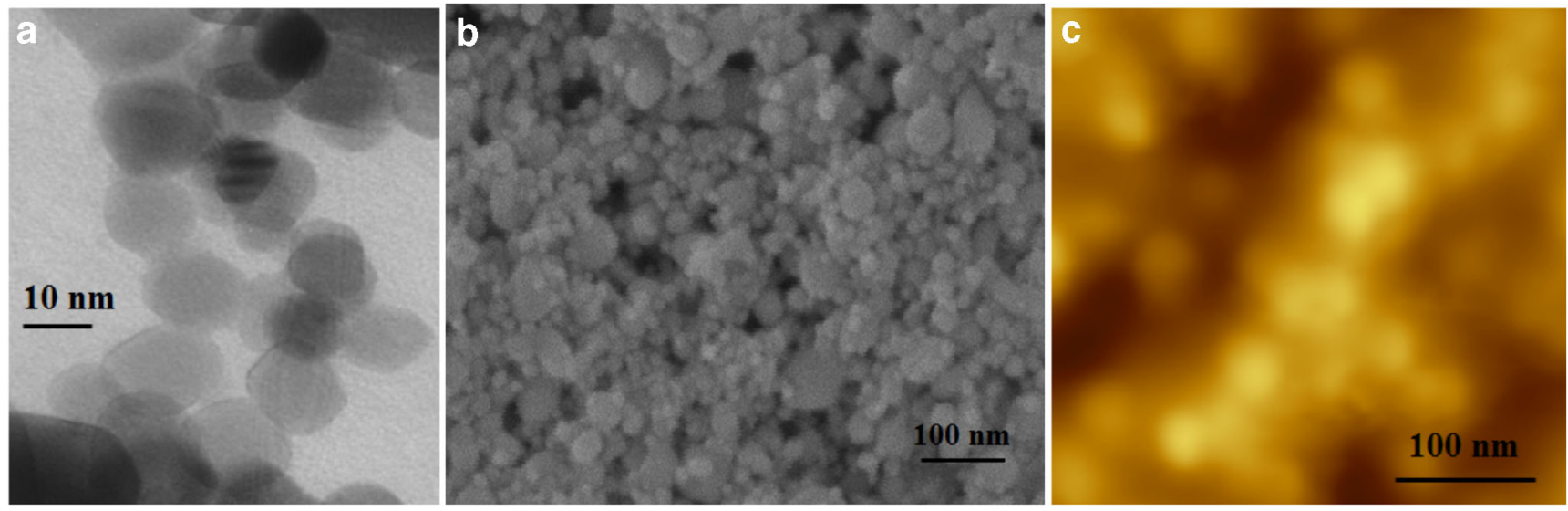

Fig. 1 a Transmission electron microscopic (TEM) image of $\mathrm{ZrO}_{2}$ nanoparticles used for the preparation of colloidal solutions for modification (deposition). b, c Stand for scanning electron microscopic (SEM) and

sizes of zirconia may slightly differ because lots of different chemicals have been used.

Figure 2 shows the ex situ FTIR spectrum (recorded in the $500-4000 \mathrm{~cm}^{-1}$ range) of air-dried $\mathrm{ZrO}_{2}$ nanoparticles deposited on the fluorine-doped tin oxide, FTO, conducting glass electrode. The bands observed at about 1600-1800 and 3400$3500 \mathrm{~cm}^{-1}$ should be assigned to the bending and stretching vibrations of the $\mathrm{O}-\mathrm{H}$ bonds originating from the absorbed water molecules [70-74]. The existence of $\mathrm{O}-\mathrm{H}$ vibrations, particularly close to $3500 \mathrm{~cm}^{-1}$, is clearly evident. The sharp band at $744 \mathrm{~cm}^{-1}$ is characteristic of monoclinic $\mathrm{ZrO}_{2}$.

Figure 3 illustrates cyclic voltammetric responses recorded during the deposition of zirconium oxide films in the colloidal mixture for modification containing zirconia nanoparticles suspended in sulfuric acid. Under such conditions, the surfaces of $\mathrm{ZrO}_{2}$ nanostructures are expected to be covered by $\mathrm{ZrO}^{2+}$, $\mathrm{ZrOH}^{3+}$, or $\left[\mathrm{Zr}_{3}(\mathrm{OH})_{4}\right]^{3+}$ oxo cations [61]. Although zirconia is not electroactive in the investigated range of potentials, it is

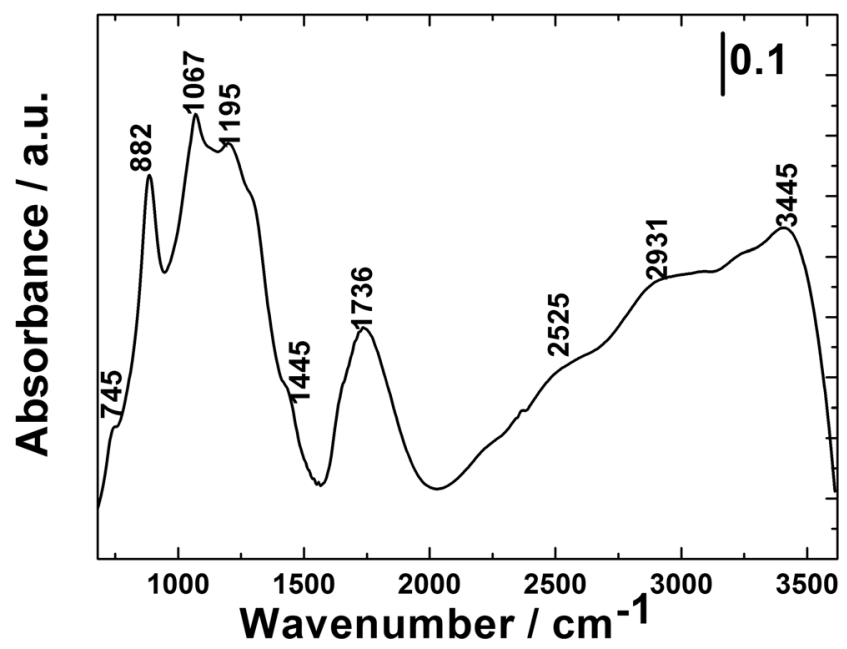

Fig. 2 FTIR spectrum (obtained by ex situ reflectance) of air-dried $\mathrm{ZrO}_{2}$ nanoparticles deposited onto fluorine-doped tin oxide (FTO) conducting glass electrode atomic force microscopic (AFM) images of $\mathrm{ZrO}_{2}$ films deposited on glassy carbon, respectively

reasonable to expect that during negative potential scans agglomeration of positively charged zirconia nanostructures proceeds by diminishing the repulsive interactions. The appearance of the peak-type current increases at about 0.5 and $0.7 \mathrm{~V}$ shall be correlated with the surface electroactivity of the carbon substrate, growth, and formation of the carboxylate- or aldehydetype surface species. The fact that currents have systematically increased during potential cycling (in the range from 0 to $1 \mathrm{~V}$ ) also reflects the capacitive charging/discharging phenomena accompanying the growth of $\mathrm{ZrO}_{2}$ film [62-64]. Once more, there is no evidence for electroactivity of $\mathrm{ZrO}_{2}$ in the investigated range of potentials [62].

Figure 4 shows transmission electron microscopic images of (a) pristine (unsupported) Pt nanoparticles, as well as of Vulcan-supported (b) Pt (Pt/V) and (c) PtRu (PtRu/V) nanoparticles. While the pristine metal nanoparticles have sizes on the level 7-8 nm (Fig. 4a), both Pt and PtRu nanoparticles supported onto Vulcan have smaller sizes, namely ca 3-

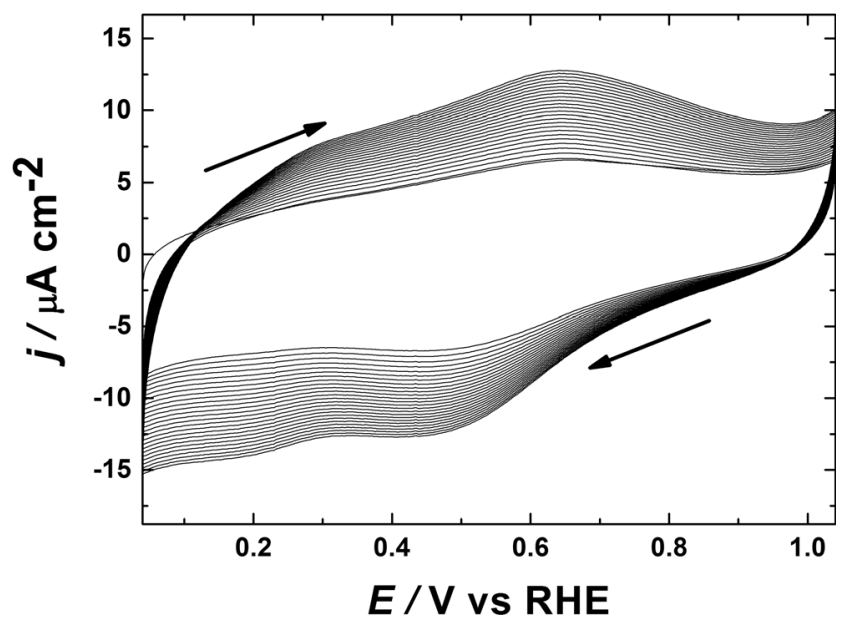

Fig. 3 Cyclic voltammetric responses recorded during potential cycling (electrodeposition) in $\mathrm{ZrO}_{2}$ colloidal suspension. Electrolyte: deaerated $0.5 \mathrm{~mol} \mathrm{dm}^{-3} \mathrm{H}_{2} \mathrm{SO}_{4}$. Scan rate: $10 \mathrm{mV} \mathrm{s}^{-1}$ 

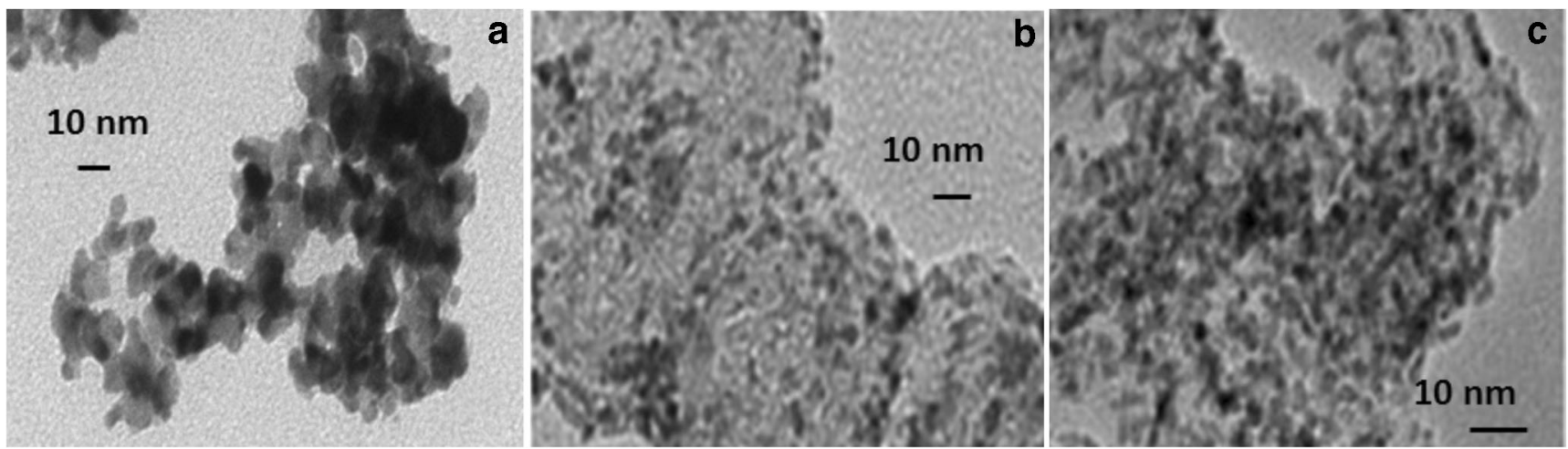

Fig. 4 TEM images of a Pt; b Vulcan-supported Pt (Pt/V); and $\mathbf{c}$ Vulcan-supported PtRu (PtRu/V) catalytic nanoparticles

$4 \mathrm{~nm}$ (Fig. $4 \mathrm{~b}$ and c). Although metal nanoparticles considered here tend to somewhat coalesce, it was established that zirconia can act as a robust inorganic matrix attenuating the tendency of nanoparticles to aggregate during prolonged electrocatalytic experiments [62-64].

\section{Electrochemical and catalytic properties of $\mathrm{Pt}$ nanoparticles}

Figure 5 illustrates cyclic voltammetric responses of pristine $\mathrm{Pt}$ nanoparticles (solid line) and of $\mathrm{Pt}$ nanoparticles deposited onto $\mathrm{ZrO}_{2}$ film on glassy carbon (dashed line). The experiments have been done in deaerated acidic medium $\left(0.5 \mathrm{~mol} \mathrm{dm}^{-3} \mathrm{H}_{2} \mathrm{SO}_{4}\right)$. The data of Fig. 5 are consistent with the view that the systems' voltammetric responses are dominated by characteristic peaks of $\mathrm{Pt}$, i.e., originating from the hydrogen adsorption in the potential range from 0 to $0.3 \mathrm{~V}$, and the Pt oxide formation peaks at potentials higher than $0.6 \mathrm{~V}$ respectively. There is no direct contribution from zirconia because $\mathrm{ZrO}_{2}$ is not electroactive in the investigated range

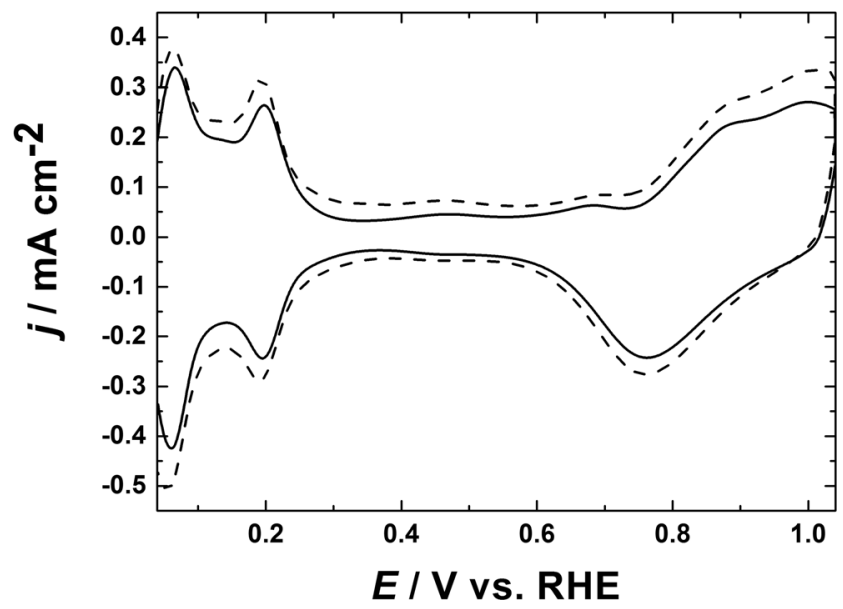

Fig. 5 Cyclic voltammetric responses of bare Pt nanoparticles (solid line) and Pt nanoparticles deposited onto zirconia (dashed line) layer on glassy carbon electrode substrate. Electrolyte, deaerated $0.5 \mathrm{~mol} \mathrm{dm}{ }^{-3} \mathrm{H}_{2} \mathrm{SO}_{4}$. Scan rate, $10 \mathrm{mV} \mathrm{s}^{-1}$. Pt loading, $100 \mu \mathrm{g} \mathrm{cm}^{-2}$ of potentials. A slight increase in the observed voltammetric currents upon supporting onto the zirconia matrix is likely to reflect the capacitive charging-discharging properties of $\mathrm{ZrO}_{2}$ [66-68]. The fact that both voltammetric responses of Fig. 5 are almost indistinguishable implies that not only the nominal loadings of Pt nanoparticles are on the same level, $100 \mu \mathrm{g} \mathrm{cm}^{-2}$, but also their electroactive surface areas are practically identical. Based on the assumption that hydrogen atoms can be adsorbed on a single platinum surface center where a total charge transfer occurs there [75], the real surface area characteristic of Pt nanoparticles has been estimated. Simply by integrating the areas under hydrogen adsorption peaks (Fig. 5) corrected for the background current and using a conversion factor of $210 \mu \mathrm{C} \mathrm{cm}^{-2}$, the value of $20 \mathrm{~m}^{2} \mathrm{~g}^{-1}$ has been obtained. Finally, the fact that hydrogen adsorption peaks (on $\mathrm{Pt}$ ) are not suppressed in the presence of $\mathrm{ZrO}_{2}$ is consistent with the view that hydroxyl groups originating from zirconia facilitate proton-dependent processes, as well as it excludes the possibility of strong adsorptive interactions with platinum nanostructures.

Figure 6 a illustrates cyclic voltammetric responses recorded in the presence of DME (saturated solution, having the DME concentration of $1.05 \mathrm{~mol} \mathrm{dm}{ }^{-3}$ ) at both pristine $\mathrm{Pt}$ (curve b) and at $\mathrm{Pt}$ deposited onto $\mathrm{ZrO}_{2}$ (curve c) relative to the conventional voltammogram characteristic of $\mathrm{Pt}$ nanoparticles recorded in the deaerated DME-free $0.5 \mathrm{~mol} \mathrm{dm}^{-3}$ sulfuric acid electrolyte (curve a). It is noteworthy that the platinum peaks appearing in the hydrogen region are significantly suppressed in the presence of DME (compare curves b and $c$ with curve a) because of strong adsorption of DME and its oxidation intermediate products on platinum. During the anodic potential scans, no clear DME oxidation currents can be found up to $0.5 \mathrm{~V}$ (curves $\mathrm{b}$ and $\mathrm{c}$ ). A sharp peak and a shoulder (DME oxidation) are apparent at ca. 0.65 and $0.75 \mathrm{~V}$; they can be correlated with oxidations of the DME intermediate species (adsorbates) and the adsorbed DME molecule itself [22-24]. The oxidation currents have declined around $0.9 \mathrm{~V}$, where the surface of $\mathrm{Pt}$ is gradually covered with the Pt oxide and, thus, becomes less active during the DME oxidation 

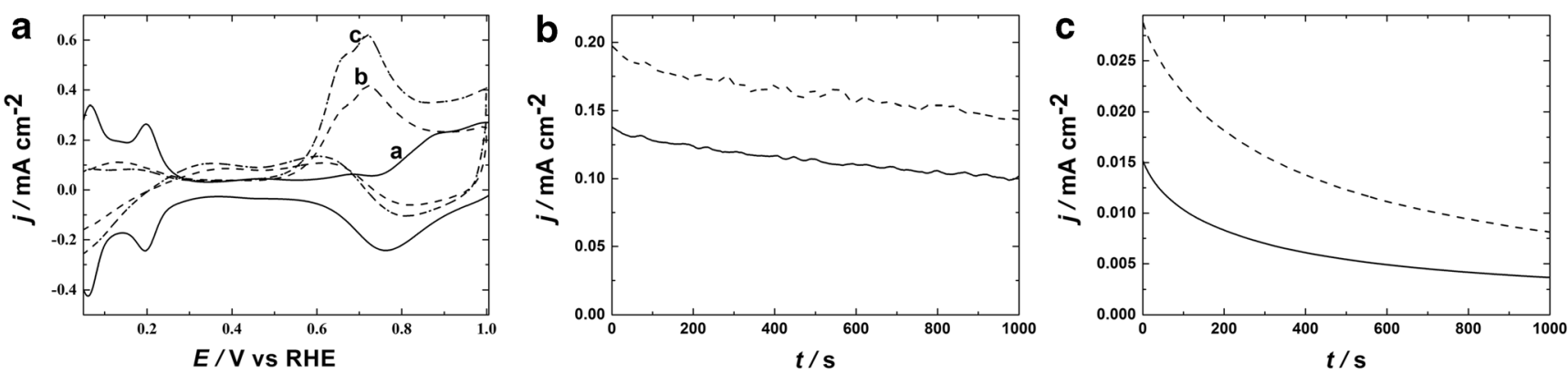

Fig. 6 a Curve (a) shows cyclic voltammetric response of Pt nanoparticles (deposited on glassy carbon electrode substrate) recorded in the absence of dimethyl ether. Curves (b) and (c) stand for the voltammetric characteristics observed in the presence of dimethyl ether (concentration, $1.05 \mathrm{~mol} \mathrm{dm}^{-3}$ ) at bare Pt and at Pt deposited onto zirconia, respectively.

reaction. In the reverse scan, the Pt oxide layer starts to be reduced (to metallic $\mathrm{Pt}$ ) below $0.8 \mathrm{~V}$, thus producing active sites they are capable to oxidize the freshly chemisorbed DME. The appearance of the broad (relatively smaller) oxidation peak currents at about 0.65 and $0.35 \mathrm{~V}$ upon scanning back to less positive potentials should be attributed to the oxidation of DME and the reaction intermediates (adsorbates) existing on $\mathrm{Pt}^{0}$. Finally, the oxidation current drops down do zero at ca. 0.2 V. Generally, the DME oxidation intermediates tend to adsorb on platinum and decrease a number of active sites and the system's electrocatalytic activity. Nevertheless, the higher DME oxidation currents have been observed for Pt nanoparticles deposited onto the zirconia matrix. Indeed, the observed current increases (Fig. 6a, curve c) should be attributed to the presence of interfacial hydroxyl groups on $\mathrm{ZrO}_{2}$ in the vicinity of Pt catalytic sites. Under such conditions, the overall tolerance to the inhibiting $\mathrm{CO}$ and other adsorbates, presumably by promoting their oxidative removal [8] is likely to be improved.

To get more information about the electrocatalytic performance of pristine Pt nanoparticles, relative to those deposited onto the zirconia matrix, during prolonged electrochemical measurements, additional current-time (chronoamperometric) measurements were performed upon application of the constant potential of 0.54 and $0.44 \mathrm{~V}$ (Fig. $6 \mathrm{~b}$ and c). Relative to cyclic voltammetry, which is sensitive to surface states of metallic catalysts at different potentials, chronoamperometry is likely to yield more reproducible steady-state electrocatalytic currents. The chronoamperometric results clearly show that current densities characteristic of the oxidation of DME were higher for Pt nanoparticles dispersed over $\mathrm{ZrO}_{2}$. The enhancement effect should not be attributed to changes in the electrochemically active surface areas of $\mathrm{Pt}$ catalysts because the respective coverages with the hydrogen adsorption peaks were almost identical both in the presence and absence of $\mathrm{ZrO}_{2}$, when the systems' cyclic voltammetric responses were recorded in the deoxygenated $\mathrm{H}_{2} \mathrm{SO}_{4}$ solutions (Fig. 5). The results support the view about the long-term "activating" role of $\mathrm{ZrO}_{2}$ during b and $\mathbf{c}$ Chronoamperometric responses illustrate the performance of bare Pt (solid lines) and Pt deposited onto zirconia (dashed lines) during oxidation of dimethyl ether upon application of b 0.54 and $\mathbf{c} 0.44 \mathrm{~V}$. Electrolyte: deaerated $0.5 \mathrm{~mol} \mathrm{dm}{ }^{-3} \mathrm{H}_{2} \mathrm{SO}_{4}$. Scan rate, $10 \mathrm{mV} \mathrm{s}{ }^{-1}$. $\mathrm{Pt}$ loading, $100 \mu \mathrm{g} \mathrm{cm}^{-2}$

electrooxidation of DME. The current increase effect presumably originates from the presence of a large population of hydroxyl groups on surfaces of zirconia nanoparticles. These $-\mathrm{OH}$ groups are likely to interact with Pt catalytic sites and induce oxidation of the CO-type passivating intermediates on platinum. Furthermore, the interfacial hydroxyl groups facilitate mobility and displacements of protons generated during the DME oxidation.

Regarding strong adsorption of DME on platinum, and to comment on the nature of the oxidation of DME adsorbates, a series of anodic stripping-type experiments was performed (Fig. 7). In the experiments, DME had been first adsorbed by conditioning Pt-modified electrodes at $0.25 \mathrm{~V}$ (in DMEsaturated $0.5 \mathrm{~mol} \mathrm{dm}^{-3} \mathrm{H}_{2} \mathrm{SO}_{4}$ ) for $100 \mathrm{~s}$. Later DME was removed from the solution through bubbling pure nitrogen for $25 \mathrm{~min}$; and, finally, the anodic DME-stripping-type cyclic voltammogram (staring from $0 \mathrm{~V}$ ) was recorded by starting

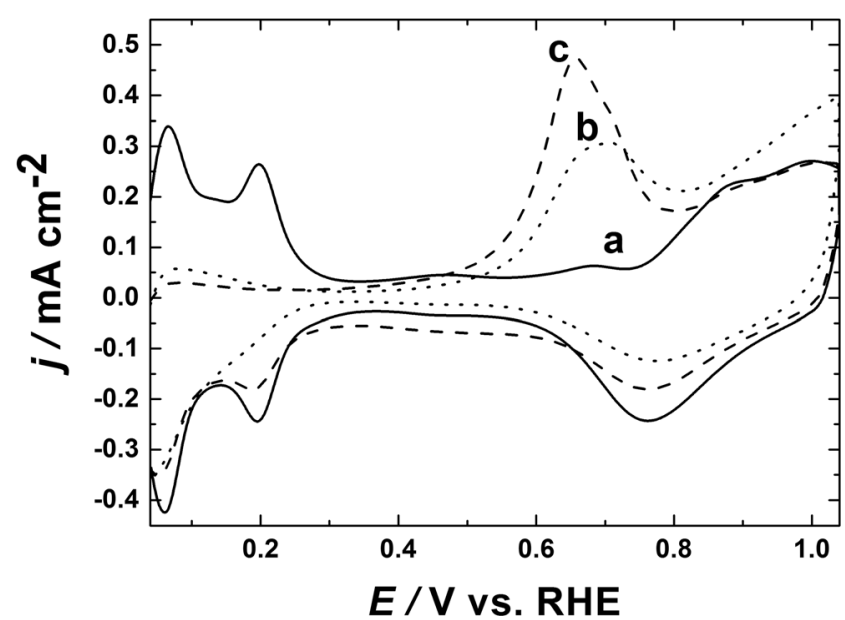

Fig. 7 Voltammetric responses recorded in the absence (curve a, bare Pt nanoparticles), and in the presence of dimethyl ether adsorbates existing at bare Pt nanoparticles (curve b, dotted line) and at Pt nanoparticles deposited onto zirconia (curve c, dashed line). Electrolyte, deaerated $0.5 \mathrm{~mol} \mathrm{dm}^{-3} \mathrm{H}_{2} \mathrm{SO}_{4}$. Scan rate, $10 \mathrm{mV} \mathrm{s}^{-1}$. Electrode substrate, glassy carbon. Pt loading, $100 \mu \mathrm{g} \mathrm{cm}^{-2}$ 
potential scanning from $0 \mathrm{~V}$ (Fig. 7, curves b and c). First, the fact that the anodic hydrogen adsorption peaks (typically appearing on Pt nanoparticles below $0.3 \mathrm{~V}$, as in curve a) were almost completely suppressed following adsorption of DME was consistent with the view about very strong adsorption of the ether on platinum. The voltammetric peaks appearing at about $0.6-0.7 \mathrm{~V}$ should be attributed to the oxidation of DME adsorbate. Indeed, the stripping-type oxidation of DME proceeded in the potential range where the catalytic metal existed as $\mathrm{Pt}^{0}$ (Fig. 7, curve a) It is noteworthy that the DME stripping oxidation peak was not only higher but was also shifted toward less positive potentials, namely from ca. 0.7 to $0.65 \mathrm{~V}$ in the case of Pt nanoaprticles deposited onto the zirconia matrix (compare dashed and dotted lines in Fig. 7). Furthermore, the onset of the DME adsorbate oxidation appeared at less positive potentials (definitely below $0.5 \mathrm{~V}$ ) in the presence of zirconia. It is reasonable to expect that, in addition to the ability of $\mathrm{ZrO}_{2}$ to provide reactive $-\mathrm{OH}$ groups, its strong acid properties could facilitate effective protonation of the oxygen atom in the ether molecule, an important dissociative step leading the $\mathrm{C}-\mathrm{O}$ bond breaking in $\mathrm{CH}_{3} \mathrm{OCH}_{3}$ [22-24].

Practical electrocatalytic systems would utilize carbon (Vulcan) carriers improving dispersion of catalytic metal nanoparticles and distribution of charge (conductivity) within the catalytic layer. Figure 8 shows the result of voltammetric oxidation of DME at Vulcan-supported Pt nanoparticles (Pt/ $\mathrm{V})$ : pristine (curve $\mathrm{b}$, dotted line) and deposited onto zirconia (curve c, dashed line). For comparison, the cyclic

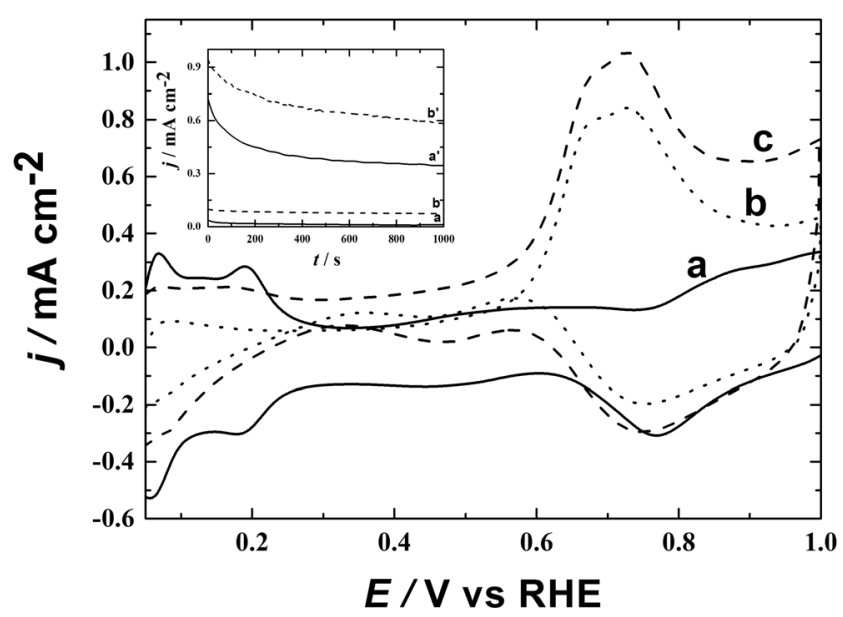

Fig. 8 Cyclic voltammetric responses recorded in the absence of dimethyl ether at bare Vulcan-supported $\mathrm{Pt}(\mathrm{Pt} / \mathrm{V})$ nanoparticles (curve a, solid line), and in the presence of dimethyl ether (concentration, $1.05 \mathrm{~mol} \mathrm{dm}^{-3}$ ) at bare $\mathrm{Pt} / \mathrm{V}$ nanoparticles (curve b; dotted line) and at $\mathrm{Pt} / \mathrm{V}$ deposited onto zirconia (Curve $\mathbf{c}$, dashed line). The inset illustrates chronoamperometric responses for the oxidation of dimethyl ether at $\mathrm{Pt} / \mathrm{V}$ nanoparticles (solid lines) upon application of $0.44 \mathrm{~V}$ and $0.54 \mathrm{~V}$ (curves a and a', respectively), and at $\mathrm{Pt} / \mathrm{V}$ deposited onto $\mathrm{ZrO}_{2}$ upon application of $0.44 \mathrm{~V}$ and $0.54 \mathrm{~V}$ (curves $\mathrm{b}$ and b', respectively). Electrolyte, deaerated $0.5 \mathrm{~mol} \mathrm{dm}^{-3} \mathrm{H}_{2} \mathrm{SO}_{4}$. Scan rate, $10 \mathrm{mV} \mathrm{s}^{-1}$. Pt/V loading, $100 \mu \mathrm{g} \mathrm{cm}^{-2}$ (Pt-metal loading, $20 \mu \mathrm{g} \mathrm{cm}^{-2}$ ). Electrode substrate, glassy carbon voltammetric response of $\mathrm{Pt} / \mathrm{V}$ in the deoxygenated (nitrogen-saturated) $0.5 \mathrm{~mol} \mathrm{dm}^{-3} \mathrm{H}_{2} \mathrm{SO}_{4}$ is also provided (curve a). By integrating the charges under the hydrogen peaks, in a manner analogous as it has been done above for Fig. 5, the electrochemically active surface area of Vulcansupported Pt centers has been found now larger (relative to simple, unsupported $\mathrm{Pt}$ ) and is equal now to ca. $39 \mathrm{~m}^{2} \mathrm{~g}^{-1}$. The DME oxidation peaks are well defined and they reach maximum values at potentials higher than $0.65 \mathrm{~V}$. Although, in the presence of $\mathrm{ZrO}_{2}$, the voltammetric currents are somewhat higher, they appear at potentials too positive to be of importance to the technology of the low-temperature fuel cells.

To further comment on the electrocatalytic performance of the systems described above during longer periods of time, additional chronoamperometric experiments have been performed upon application of two potentials, $0.44 \mathrm{~V}$ (inset to Fig. 8, curves a and b) 10C) and $0.54 \mathrm{~V}$ (inset to Fig. 8, curves a' and b'), at which oxidation of DME is operative. The characteristic chronoamperograms (Fig. 8, inset) are in the form of steadystate current responses. In comparison to the voltammetric performance during oxidation of DME, the addition of $\mathrm{ZrO}_{2}$ seems to result in more pronounced enhancement of the electrocatalytic currents under chronoamperometric conditions.

\section{Electrooxidation of DME at PtRu nanoparticles}

Electrooxidation of DME at the Vulcan-supported PtRu $(\mathrm{PtRu} / \mathrm{V})$ catalyst has also been considered here (Fig. 9). In the absence of DME (curve a), the cyclic voltammetric response of PtRu/V system exhibits the characteristic hydrogen adsorption currents at lower potentials $(<0.25 \mathrm{~V})$ as well as certain current increases originating formation of the mixed $\mathrm{Pt}$ and $\mathrm{Ru}$ oxide species at higher potentials $(>0.5 \mathrm{~V})$. In the presence of DME, its oxidation at PtRu nanoparticles leads to single broad peaks (Fig. 9) rather than two peaks that have been observed at Pt nanoparticles (Figs. 5 and 8). The appearance of the much broader DME peak in the case of PtRu (relative to Pt) can be rationalized in terms of the distinct (apparently higher) activity of pristine Pt, relative to alloyed $\mathrm{Pt}$ (in PtRu); on the other hand, the Ru-component of PtRu tends to induce the oxidative removal of poisoning adsorbates. No oxidation current has been observed above $0.9 \mathrm{~V}$, where the PtRu surface becomes gradually covered with oxides and, therefore, is becoming less active during the DME oxidation [19, 26, 31]. Careful examination of the oxidation of DME in $0.5 \mathrm{~mol} \mathrm{dm}{ }^{-3} \mathrm{H}_{2} \mathrm{SO}_{4}$ at PtRu/V nanoparticles (Curve b, dotted line), relative to the performance of PtRu/V nanoparticles supported onto zirconia, implies that the addition of $\mathrm{ZrO}_{2}$ to the electrocatalytic interface results in shifting of the onset potential to less positive values (ca. $0.3 \mathrm{~V}$ ) and in the increase in the DME oxidation currents.

Further diagnostic experiments (oriented on the potential application in low-temperature fuel cells) aimed at monitoring long-term current-time (chronoamperometric) responses (Fig. 


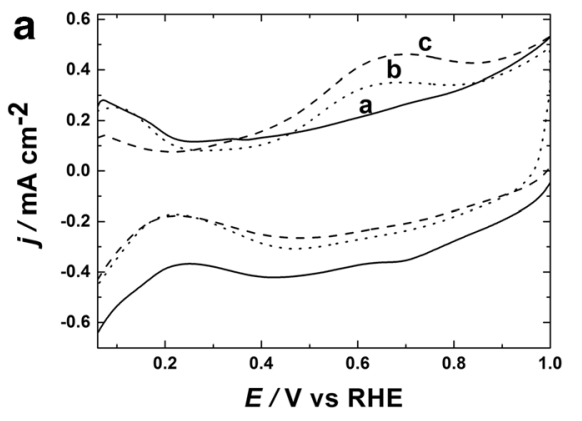

Fig. 9 a Curve (a) shows cyclic voltammetric response of Vulcansupported PtRu $(\mathrm{PtRu} / \mathrm{V})$ nanoparticles (deposited on glassy carbon electrode substrate) recorded in the absence of dimethyl ether. Curves (b) and (c) stand for the voltammetric characteristics observed in the presence of dimethyl ether (concentration, $1.05 \mathrm{~mol} \mathrm{dm}^{-3}$ ) at bare $\mathrm{PtRu} / \mathrm{V}$ and at $\mathrm{PtRu} / \mathrm{V}$ deposited onto zirconia, respectively. b, c Chronoamperometric
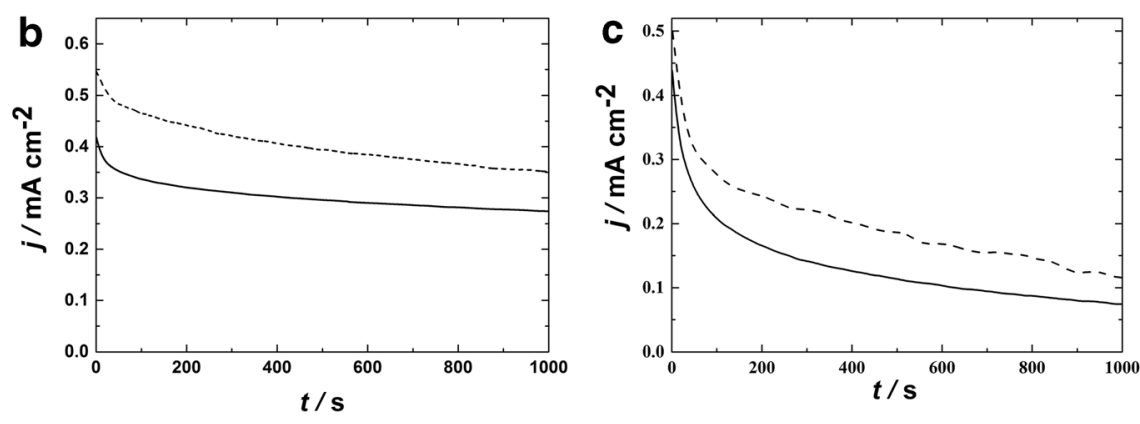

responses illustrate the performance of bare $\mathrm{PtRu} / \mathrm{V}$ (solid lines) and $\mathrm{PtRu} / \mathrm{V}$ deposited onto zirconia (dashed lines) during oxidation of dimethyl ether upon application of a 0.54 and $\mathbf{c} 0.44 \mathrm{~V}$. Electrolyte, deaerated $0.5 \mathrm{~mol} \mathrm{dm}^{-3} \mathrm{H}_{2} \mathrm{SO}_{4}$. Scan rate, $10 \mathrm{mV} \mathrm{s}^{-1}$. PtRu/V loading, $100 \mu \mathrm{g} \mathrm{cm}^{-2}$ (PtRu-metal loading, $20 \mu \mathrm{g} \mathrm{cm}^{-2}$ )

$9 \mathrm{~b}$ and c) at two potentials 0.54 and $0.44 \mathrm{~V}$. As in the case of voltammetric examination, the chronoamperometric currents for the oxidation of DME have been higher for PtRu/V dispersed onto $\mathrm{ZrO}_{2}$ (in comparison with pristine $\mathrm{PtRu} / \mathrm{V}$ ). Here, the $-\mathrm{OH}$ groups originating from zirconia seem to induce electrocatalytic activity the metal $(\mathrm{Pt}, \mathrm{Ru})$ components. It is noteworthy that the activating interactions between zirconia and ruthenium oxides during oxidations were reported before $[52,54]$. Having in mind the chemical similarities of $\mathrm{ZrO}_{2}$ and $\mathrm{TiO}_{2}$, as well the fact that the latter oxide is known to interact with Ru-oxo species, it is reasonable to expect that nanostructured zirconia should increase the activity of the ruthenium component in PtRu electrocatalysts. Such enhancement effects were observed earlier during oxidation of ethanol and formic acid [63, 64], and they were attributed to the high population of hydroxyl groups and high mobility of protons at the zirconia-containing interface.

Despite differences in possible mechanisms for the electrooxidation of DME at Pt and PtRu catalysts, the dissociation of the $\mathrm{H}_{3} \mathrm{C}-\mathrm{O}-\mathrm{CH}_{3}$ molecule, which involves $\mathrm{C}-\mathrm{O}$ bond breaking, the formation of methanol or methanolic residues, and CO-type poisoning adsorbates, is operative [19, 22-24]. Based on our present observations, it is reasonable to expect that the strong acidity of the zirconia additive facilitates the $\mathrm{C}-$ $\mathrm{O}$ bond breaking and shifts the onset potential of the DME oxidation toward less positive values. Such effects are clearly visible during the oxidation of DME adsorbates on Pt (Fig. 7) and, particularly, when the reaction has been pursued at PtRu (Fig. 9). Regarding the formation of methanol or methanolic residues as reaction intermediates, we have performed additional diagnostic (both voltammetric and chronoamperometric) experiments for the oxidation of methanol (Fig. 10) using pristine $\mathrm{PtRu}$ (solid line) and PtRu deposited onto zirconia (dashed lines). The observations can be rationalized as follows. First, both in the presence and absence of $\mathrm{ZrO}_{2}$, PtRu exhibits its usual electrocatalytic activity during the oxidation of methanol. Second, by analogy to the behavior of DME, the application of nanostructured $\mathrm{ZrO}_{2}$ as a matrix for dispersed PtRu nanoparticles leads to increases of catalytic currents during electrooxidation of methanol in an acid medium (both under voltammetric and chronoamperometric conditions) as well. Furthermore, the onset potentials for the electrooxidation of both methanol and DME are comparable. Nevertheless, the observed electrocatalytic current densities are higher in the case of the methanol oxidation, relative to the performance of DME. The latter process is mechanistically more complex and is kinetically more sluggish. The main advantage coming from the use of zirconia as the matrix for PtRu during the oxidation of DME is the observed shift of the DME oxidation onset potential

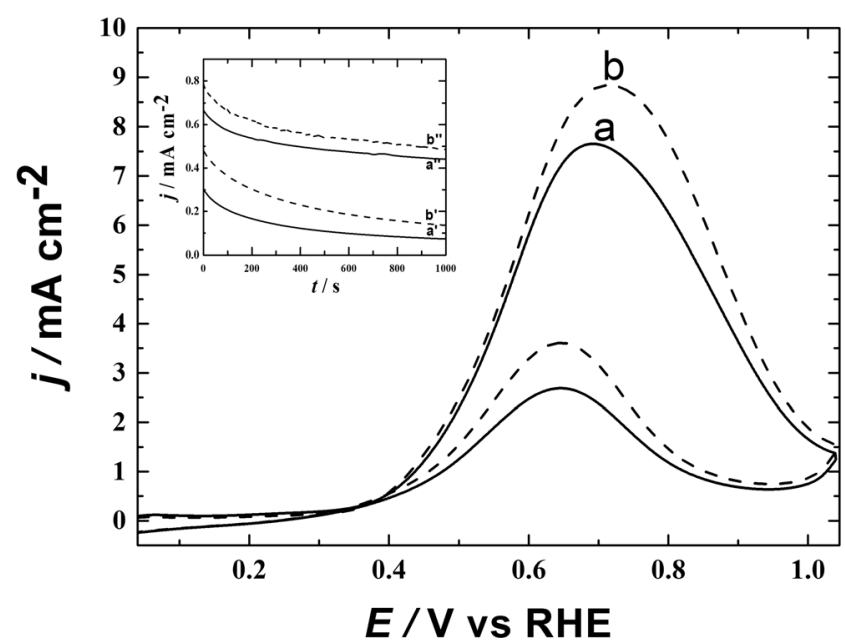

Fig. 10 Cyclic voltammetric responses recorded in the presence of methanol (concentration, $1.05 \mathrm{~mol} \mathrm{dm}^{-3}$ ) at $\mathbf{a}$ bare $\mathrm{PtRu} / \mathrm{V}$ nanoparticles (solid line) and $\mathbf{b} \mathrm{PtRu} / \mathrm{V}$ deposited onto zirconia (dashed line). Inset illustrates chronoamperometric responses for the oxidation of methanol at $\mathrm{PtRu} / \mathrm{V}$ nanoparticles (solid lines) upon application of $0.44 \mathrm{~V}$ and $0.54 \mathrm{~V}$ (curves a' and a", respectively) and at $\mathrm{PtRu} / \mathrm{V}$ deposited onto $\mathrm{ZrO}_{2}$ upon application of $0.44 \mathrm{~V}$ and $0.54 \mathrm{~V}$ (curves b' and b", respectively). Electrolyte, deaerated $0.5 \mathrm{~mol} \mathrm{dm}^{-3} \mathrm{H}_{2} \mathrm{SO}_{4}$. Scan rate, $10 \mathrm{mV} \mathrm{s}^{-1}$. $\mathrm{PtRu} / \mathrm{V}$ loading, $100 \mathrm{\mu g} \mathrm{cm}^{-2}$ (PtRu-metal loading, $20 \mu \mathrm{g} \mathrm{cm}^{-2}$ ). Electrode substrate, glassy carbon 
toward less positive values. Such a feature has not been a case during the methanol oxidation.

Despite differences in the oxidation mechanisms, it is reasonable to attribute the enhancement effects observed in both cases (Figs. 9 and 10) to the ability of hydroxyl groups to promote the oxidative removal of CO-type (and other) poisoning adsorbates. But in the case of the DME oxidation, one should also take into account, in addition to the $\mathrm{ZrO}_{2}$-induced acid catalytic effects inducing $\mathrm{C}-\mathrm{O}$ bond breaking [22-24], the feasibility of specific interactions between noble metal nanoparticles and zirconia. For example, possible interactions of zirconia (interfacial hydroxyl groups) with the ruthenium component (of PtRu) should facilitate the formation of highly active Ru-oxo species [8]. Among other possible scenarios is the existence of small amounts (relative to $\mathrm{Pt}^{0}$ ) of partially oxidized Pt centers in the vicinity of zirconia [76], as well as the formation of the oxygen-deficient electronically conducting $\mathrm{ZrO}_{2-x}$, as postulated elsewhere [77]. The actual activation effects are obviously strongly dependent on the structure and composition of the catalyst's surface and may involve distinct pathways and even more active intermediates. Recent studies clearly demonstrate that Pt catalysts having certain morphologies and structures, or subject to interfacial modifications can exhibit better performance during DME electrooxidation [78-81]. Further research is along this line.

\section{Conclusions}

We demonstrate here that deposition of Pt and bimetallic PtRu nanoparticles onto nanostructured zirconia support leads to the enhancement of their catalytic activities toward electrooxidation of dimethyl ether (DME). It is reasonable to expect that the ability of zirconia to induce acid catalysis (weakening of $\mathrm{C}-\mathrm{O}$ bond in the ether), increase proton mobility, and to donate active hydroxyl groups at the electrocatalytic interface are responsible for the observed catalytic enhancement effects. Mutual activating interactions between $\mathrm{ZrO}_{2}$ and platinum or ruthenium components resulting in the formation of sub-stoichiometric oxide and changes in the electronic properties of $\mathrm{Pt}$ and $\mathrm{Ru}$ are also feasible. The fact that the onset potential for the oxidation of DME is somewhat shifted toward less positive potentials in the presence of zirconia is of potential practical importance.

Funding information This work was supported by the National Science Center (Poland) under the Opus Project 2018/29/B/ST5/02627.

Open Access This article is licensed under a Creative Commons Attribution 4.0 International License, which permits use, sharing, adaptation, distribution and reproduction in any medium or format, as long as you give appropriate credit to the original author(s) and the source, provide a link to the Creative Commons licence, and indicate if changes were made. The images or other third party material in this article are included in the article's Creative Commons licence, unless indicated otherwise in a credit line to the material. If material is not included in the article's Creative Commons licence and your intended use is not permitted by statutory regulation or exceeds the permitted use, you will need to obtain permission directly from the copyright holder. To view a copy of this licence, visit http://creativecommons.org/licenses/by/4.0/.

\section{References}

1. Watanabe M, Uchida H (2009) In: Vielstich W, Gasteiger HA, Lamm A, Yokokawa H (eds.) Handbook of fuel cells - fundamentals, technology and applications, Volume 5: Advances in electocatalysis, materials, diagnostics and durability, Wiley, New York

2. Maillant F, Pronkin S, Savinova ER (2009) In: Vielstich W, Gasteiger HA, Lamm A, Yokokawa H (eds.) Handbook of fuel cells - fundamentals, technology and applications, Volume 5: Advances in electocatalysis, materials, diagnostics and durability, Wiley, 2009

3. Campelo JM, Luna D, Luque R, Marinas JM, Romero AA (2009) Sustainable preparation of supported metal nanoparticles and their applications in catalysis. Chem Sus Chem 2(1):18-45

4. Leger JM (2005) Preparation and activity of mono- or bi-metallic nanoparticles for electrocatalytic reactions. Electrochim Acta 50(15):3123-3129

5. Singh AK, Xu Q (2013) Synergistic catalysis over bimetallic alloy nanoparticles. ChemCatChem 5(3):652-676

6. Zhou WP, Axnada S, White MG, Adzic RR, Hrbek J (2011) Enhancement in ethanol electrooxidation by $\mathrm{SnOx}$ nanoislands grown on $\mathrm{Pt}(111)$ : effect of metal oxide-metal interface sites. J Phys Chem C 115(33):16467-16473

7. Sim K-S, Lim S-M, Kwen H-D, Choi S-H (2011) Electrocatalytic activity for $\mathrm{CO}, \mathrm{MeOH}$, and $\mathrm{EtOH}$ oxidation on the surface of Pt$\mathrm{Ru}$ nanoparticles supported by metal oxide. J Nanomaterials 614983

8. Kulesza PJ, Pieta IS, Rutkowska IA, Wadas A, Marks D, Klak K, Stobinski L, Cox JA (2013) Electrocatalytic oxidation of small organic molecules in acid medium: enhancement of activity of noble metal nanoparticles and their alloys by supporting or modifying them with metal oxides. Electrochim Acta 110:474-483

9. Lasch K, Hayn G, Jorissen L, Garche J, Besenhardt O (2002) Mixed conducting catalyst support materials for the direct methanol fuel cell. J Power Sources 105(2):305-310

10. Macak JM, Barczuk PJ, Tsuchiya H, Nowakowska MZ, Ghicov A, Chojak M, Bauer S, Virtanen S, Kulesza PJ, Schmuki P (2005) Self-organized nanotubular $\mathrm{TiO}_{2}$ matrix as support for dispersed $\mathrm{Pt} / \mathrm{Ru}$ nanoparticles: enhancement of the electrocatalytic oxidation of methanol. Electrochem Commun 7(12):1417-1422

11. Lamy C, Lima A, LeRhun V, Delime F, Countanceau C, Leger J-M (2002) Recent advances in the development of direct alcohol fuel cells (DAFC). J Power Sources 105(2):283-296

12. Napporn WT, Laborde H, Leger J-M, Lamy C (1996) Electrooxidation of $\mathrm{C} 1$ molecules at Pt-based catalysts highly dispersed into a polymer matrix: effect of the method of preparation. $\mathrm{J}$ Electroanal Chem 404(1):153-159

13. Grinberg VA, Maiorova NA, Pasynskii AA, Emets VV, Shiryaev AA, Vysotskii VV, Gerasimov VK, Matveev VV, Nizhnikovskii E, Andreev VN (2017) Nanostructured catalysts for direct electrooxidation of dimethyl ether based on bi- and trimetallic $\mathrm{Pt}-$ $\mathrm{Ru}$ and $\mathrm{Pt}-\mathrm{Ru}-\mathrm{Pd}$ alloys prepared from coordination compounds. Russ J Coord Chem 43(4):206-212

14. Kerangueven G, Coutanceau C, Sibert E, Hahn F, Leger J-M, Lamy C (2006) Mechanism of di(methyl)ether (DME) electrooxidation at 
platinum electrodes in acid medium. J Appl Electrochem 36(4): $441-448$

15. Rutkowska IA, Sek JP, Marks E, Zelenay P, Kulesza PJ (2015) Activation of platinum-based centers through modification with metal Oxo species toward electrocatalytic oxidation of dimethyl ether and methanol. ECS Transaction 66(2):35-44

16. Yudanov IV, Matveev AV, Neyman KM, Rosch N (2008) How the $\mathrm{C}-\mathrm{O}$ bond breaks during methanol decomposition on nanocrystallites of palladium catalysts. J Am Chem Soc 130(29): 9342-9352

17. Dumont JH, Martinez U, Chung HT, Zelenay P (2016) Ternary $\mathrm{PtRuPd} / \mathrm{C}$ catalyst for high-performance, low-temperature direct dimethyl ether fuel cells. ChemElectroChem 3:1-7

18. Li Q, Wen X, Wu G, Chung HT, Gao R, Zelenay P (2015) Highactivity $\mathrm{PtRuPd} / \mathrm{C}$ catalyst for direct dimethyl ether fuel cells. Angew Chem Int Ed 54(26):7524-7528

19. Li Q, Wu G, Johnston CM, Zelenay P (2014) Direct dimethyl ether fuel cell with much improved performance. Electrocatalysis 5(3): 310-317

20. Gavriel B, Sharabi R, Elbaz L (2017) Direct electro-oxidation of dimethyl ether on $\mathrm{Pt}-\mathrm{Cu}$ nanochains. ChemSusChem 10:1-7

21. Serov A, Kwak C (2009) Progress in development of direct dimethyl ether fuel cells. Appl Catal B-Environ 91(1-2):1-10

22. Pan LM, Zhou ZY, Chen DJ, Sun SG (2008) Electrochemical and in situ FTIR studies of adsorption and oxidation of dimethyl ether on platinum electrode. Acta Phys -Chim Sin 24(10):1739-1744

23. Zhang Y, Lu LL, Tong YJ, Osawa M, Ye S (2008) Electrochemical and infrared study of electro-oxidation of dimethyl ether (DME) on platinum polycrystalline electrode in acid solutions. Electrochim Acta 53(21):6093-6103

24. Lu LL, Yin GP, Tong YJ, Zhang Y, Gao YZ, Osawa M, Ye S (2008) Electrochemical behaviors of dimethyl ether on platinum single crystal electrodes. Part I: Pt(111). J Electroanal Chem 619: 143-151

25. Shao MH, Warren J, Marinkovic NS, Faguy PW, Adzic RR (2005) In situ ATR-SEIRAS study of electrooxidation of dimethyl ether on a Pt electrode in acid solutions. Electrochem Commun 7(5):459465

26. Liu Y, Muraoka M, Mitsushima S, Ota KI, Kamiya N (2007) Electrochemical and ATR-FTIR study of dimethyl ether and methanol electro-oxidation on sputtered Pt electrode. Electrochim Acta 52(19):5781-5788

27. Gasteiger HA, Markovic NM, Ross PN, Cairns EJ (1993) Methanol electrooxidation on well-characterized platinum-ruthenium bulk alloys. J Phys Chem 97(46):12020-12029

28. Chu D, Gilman S (1996) Methanol electro-oxidation on unsupported Pt-Ru alloys at different temperatures. J Electrochem Soc 143(5): $1685-1689$

29. Frelink T, Visscher W, Ween JARV (1996) Measurement of the Ru surface content of electrocodeposited PtRu electrodes with the electrochemical quartz crystal microbalance: implications for methanol and CO electrooxidation. Langmuir 12(15):3702-3708

30. Hable CT, Wrighton MS (1993) Electrocatalytic oxidation of methanol and ethanol: a comparison of platinum-tin and platinumruthenium catalyst particles in a conducting polyaniline matrix. Langmuir 9(11):3284-3290

31. Liu Y, Mitsushima S, Ota K, Kamiya N (2006) Electro-oxidation of dimethyl ether on $\mathrm{Pt} / \mathrm{C}$ and $\mathrm{PtMe} / \mathrm{C}$ catalysts in sulfuric acid. Electrochim Acta 51(28):6503-6509

32. Wang J, Nakajima H, Kita H (1988) Enhancement in methanol oxidation by molybdenum modification of Pt-SPE electrodes. J Electroanal Chem 250(1):213-217

33. Gotz M, Wendt H (1998) Binary and ternary anode catalyst formulations including the elements W, Sn and Mo for PEMFCs operated on methanol or reformate gas. Electrochim Acta 43(24):3637-3644
34. Wang K, Gasteiger HA, Markovic MN, Ross PN Jr (1996) On the reaction pathway for methanol and carbon monoxide electrooxidation on Pt-Sn alloy versus Pt-Ru alloy surfaces. Electrochim Acta 41(16):2587-2593

35. Lasch K, Jorissen L, Garche J (1999) The effect of metal oxides as co-catalysts for the electro-oxidation of methanol on platinum-ruthenium. J Power Sources 84(2):225-230

36. Zhang Q, Li Z, Wang S, Xing W, Yu R, Yu X (2008) The electrooxidation of dimethyl ether on platinum-based catalyst. Electrochim Acta 53(28):8298-8304

37. Damjanovic A, Genshaw MA, Bockris JOM (1967) The role of hydrogen peroxide in oxygen reduction at platinum in $\mathrm{H}_{2} \mathrm{SO}_{4}$ solution. J Electrochem Soc 114(5):466-471

38. Haner AN, Ross PN (1991) Electrochemical oxidation of methanol on tin-modified platinum single-crystal surfaces. J Phys Chem 95(9):3740-3746

39. Wang J, Nakajima H, Kita H (1990) Metal electrodes bonded on solid polymer electrolyte membrane (SPE) - VI. Methanol oxidation on molybdenum modified Pt-SPE electrode. Electrochim Acta 35(2):323-328

40. Watanabe M, Igarashi H, Fujino T (1999) Design of CO tolerant anode catalysts for polymer electrolyte fuel cell. Electrochemistry 67(12):1194-1196

41. Kerangueven G, Coutanceau C, Sibert E, Léger J-M, Lamy C (2006) Methoxy methane (dimethyl ether) as an alternative fuel for direct fuel cells. J Power Sources 157(1):318-324

42. Antolini E, Gonzalez ER (2009) Ceramic materials as supports for low-temperature fuel cell catalysts. Solid State Ionics 180(9-10): 746-763

43. Shao YY, Liu J, Wang Y, Lin YH (2009) Novel catalyst support materials for PEM fuel cells: current status and future prospects. J Mater Chem 19(1):46-59

44. Lai L, Huang G, Wang X, Weng J (2011) Preparation of Pt nanoparticle-loaded three-dimensional $\mathrm{Fe}_{3} \mathrm{O}_{4}$ /carbon with high electro-oxidation activity. Carbon 49(5):1581-1587

45. Chen Y, Zhou Y, Tang Y, Lu T (2010) Electrocatalytic properties of carbon-supported Pt-Ru catalysts with the high alloying degree for formic acid electrooxidation. J Powers Sources 195(13):4129 4234

46. Mazurkiewicz-Pawlica M, Malolepszy A, Mikolajczuk-Zychora A, Mierzwa B, Borodzinski A, Stobinski L (2019) A simple method for enhancing the catalytic activity of Pd deposited on carbon nanotubes used in direct formic acid fuel cells. Appl Surf Sci 476:806814

47. Mikolajczuk-Zychora A, Borodzinski A, Kedzierzawski P, Mierzwa B, Mazurkiewicz-Pawlicka M, Stobinski L, Ciecierska E, Zimoch A, Opallo M (2016) Highly active carbon supported Pd cathode catalysts for direct formic acid fuel cells. App Surf Sci 388:645-652

48. Antolini E (2009) Carbon supports for low-temperature fuel cell catalysts. Appl Catal B Environ 88(1-2):1-24

49. Liu Z, Hong L (2007) Electrochemical characterization of the electrooxidation of methanol, ethanol and formic acid on $\mathrm{Pt} / \mathrm{C}$ and $\mathrm{PtRu} / \mathrm{C}$ electrodes. J Appl Electrochem 37(4):505-510

50. Napolskii KS, Barczuk PJ, Vassiliev SY, Veresov AG, Tsirlina GA, Kulesza PJ (2007) Templating of electrodeposited platinum group metals as a tool to control catalytic activity. Electrochim Acta 52(28):7910-7919

51. Rutkowska IA, Kulesza PJ (2018) In: Wandelt K (ed) Encyclopedia of interfacial chemistry: surface science and electrochemistry, 1 st ed. Amsterdam, Elsevier

52. Trasatti S (1999) In: Wieckowski A (ed) Interfacial electrochemistry theory, experiment and applications, Marcel Dekker, New York

53. Trasatti S (1987) Oxide/aqueous solution interfaces, interplay of surface chemistry and electrocatalysis. Mat Chem Phys 16(2): $157-174$ 
54. Trasatti S (1980) Electrocatalysis by oxides - attempt at a unifying approach. J Electroanal Chem Interf Electrochem 111(1):125-131

55. Koning U, Schultze JW (1999) In: Wieckowski A (ed) Interfacial electrochemistry theory, experiment and applications, Marcel Dekker, New York

56. Amberg M, Günter JR (1996) Metastable cubic and tetragonal zirconium dioxide, prepared by thermal oxidation of the dichalcogenides. Solid State Ionics 84(3-4):313-321

57. Lee SM, Oh SH, Cho WI, Jang H (2006) The effect of zirconium oxide coating on the lithium nickel cobalt oxide for lithium secondary batteries. Electrochim Acta 52(4):1507-1513

58. Lu J, Zang JB, Shan SX, Huang H, Wang YH (2008) Synthesis and characterization of core-shell structural MWNT-zirconia nanocomposites. Nano Lett 8(11):4070-4074

59. Yadav GD, Nair JJ (1999) Sulfated zirconia and its modified versions as promising catalysts for industrial processes. Micropor Mesopor Mat 33(1-3): 1-48

60. Johnson GE, Mitric R, Tyo EC, Bonacic-Koutecky V, Castleman AW Jr (2008) Stoichiometric zirconium oxide cations as potential building blocks for cluster assembled catalysts. J Am Chem Soc 130(42):13912-13920

61. Cotton FA, Wilkinson G (1980) Advanced inorganic chemistry, 4th edn. Wiley, New York

62. Rutkowska IA, Kulesza PJ (2014) Electrocatalytic oxidation of ethanol in acid medium: enhancement of activity of Vulcansupported platinum-based nanoparticles upon immobilization within nanostructured zirconia matrices. Funct Mater Lett 7(06): 1440005

63. Rutkowska IA, Zoladek S, Kulesza PJ (2015) Polyoxometallateassisted integration of nanostructures of $\mathrm{Au}$ and $\mathrm{ZrO}_{2}$ to form supports for electrocatalytic PtRu nanoparticles: enhancement of their activity toward oxidation of ethanol. Electrochim Acta 162:215223

64. Rutkowska IA (2016) Enhancement of oxidation of formic acid in acid medium on zirconia-supported phosphotungstate-decorated noble metal (Pd, Pt) nanoparticles. Aust J Chem 69(4):394-402

65. Zoladek S, Rutkowska IA, Kulesza PJ (2011) Enhancement of activity of platinum towards oxidation of ethanol by supporting on titanium dioxide containing phosphomolybdate-modified gold nanoparticles. Appl Surf Sci 257(19):8205-8210

66. Rutkowska IA, Koster MD, Blanchard GJ, Kulesza PJ (2014) Enhancement of ethanol oxidation at Pt and PtRu nanoparticles dispersed over hybrid zirconia-rhodium supports. J Power Sources 272:681-688

67. Rutkowska IA, Wadas A, Kulesza PJ (2016) Enhancement of oxidative electrocatalytic properties of platinum nanoparticles by supporting onto mixed $\mathrm{WO}_{3} / \mathrm{ZrO}_{2}$ matrix. Appl Surf Sci 388: 616-623
68. Rutkowska IA, Wadas A, Kulesza PJ (2016) Mixed layered $\mathrm{WO}_{3}$ / $\mathrm{ZrO}_{2}$ films (with and without rhodium) as active supports for PtRu nanoparticles: enhancement of oxidation of ethanol. Electrochim Acta 210:575-587

69. $\mathrm{Xu} \mathrm{C}$, Shen PK (2004) Novel $\mathrm{Pt} / \mathrm{CeO}_{2} / \mathrm{C}$ catalysts for electrooxidation of alcohols in alkaline media. Chem Commun (19):2238-2239

70. Hao Y, Li J, Yang X, Wang X, Lu L (2004) Preparation of $\mathrm{ZrO}_{2}-$ $\mathrm{Al}_{2} \mathrm{O}_{3}$ composite membranes by sol-gel process and their characterization. Mater Sci Eng A 367(1-2):243-247

71. Chen S, Yin Y, Wang D, Liu Y, Wang X (2005) Structures, growth modes and spectroscopic properties of small zirconia clusters. J Cryst Growth 282(3-4):498-505

72. Jayakumar S, Ananthapadmanabhan PV, Perumal K, Thiyagarajan TK, Mishra SC, Su LT, Tok AIY, Guo J (2011) Characterization of nano-crystalline $\mathrm{ZrO}_{2}$ synthesized via reactive plasma processing. Mat Sci Eng B 176(12):894-899

73. Phillippe CM, Mazdiyasni KS (1971) Infrared and Raman spectra of zirconia polymorphs. J Am Ceram Soc 54(5):254-258

74. Feinberg A, Perry CH (1981) Structural disorder and phase transitions in $\mathrm{ZrO}_{2}-\mathrm{Y}_{2} \mathrm{O}_{3}$ system. J Phys Chem Solids 42(6):513-518

75. Trasatti S, Petrii OA (1991) Real surface area measurements in electrochemistry. Pure Appl Chem 63(5):711-734

76. Bhogeswararao S, Srinivas D (2012) Intramolecular selective hydrogenation of cinnamaldehyde over $\mathrm{CeO}_{2}-\mathrm{ZrO}_{2}$-supported Pt catalysts. J Catal 285(1):31-40

77. Malolepszy M, Mazurkiewicz M, Stobinski L, Lesiak B, Kover L, Toyh J, Mierzwa B, Borodzinski A, Nitze F, Wagberg T (2015) Deactivation resistant $\mathrm{Pd}-\mathrm{ZrO}_{2}$ supported multiwall carbon nanotubes catalyst for direct formic acid fuel cells. Int J Hydrog Energy 40(46):16724-16733

78. Si F, Chen X, Liang L, Li C, Liao J, Liu C, Zhang X, Xing W (2011) $\mathrm{Pt} / \mathrm{C}$ anodic catalysts with controlled morphology for direct dimethyl ether fuel cell: the role of consecutive surface. Electrochim Acta 56(17):5966-5971

79. Roling LT, Herron JA, Budiman W, Ferrin P, Mavrikakis M (2016) Dimethyl ether electro-oxidation on platinum surfaces. Nano Energy 29:428-438

80. Votchenko EY, Kubanova MS, Smirnova NV, Petrii OA (2010) Adsorption and electrooxidation of dimethyl ether on platinized platinum electrode in sulfuric acid solution. Russ J Electrochem 46(2):212-217

81. Gavriel B, Sharabi R, Elbaz L (2017) Direct electro-oxidation of dimethyl ether on Pt-Cu nanochains. Chem Sus Chem 10(15): 3069-3074

Publisher's note Springer Nature remains neutral with regard to jurisdictional claims in published maps and institutional affiliations. 